MARZENA DYCHT

Wydział Nauk Pedagogicznych

Uniwersytet Kardynała Stefana Wyszyńskiego

Warszawa
Forum Pedagogiczne $2016 / 1$

Wpłynęło: 17.11 .2015

Zatwierdzono do druku: 5.03.2016

\title{
REHABILITACJA I EDUKACJA OSÓB Z DYSFUNKCJA WZROKU W DOBIE ROZWOJU NAUK I NOWYCH TECHNOLOGII
}

Streszczenie: Współczesny człowiek stoi w obliczu technologicznej rewolucji, spowodowanej intensywnym rozwojem nauk, która wymusza coraz szybciej postępujące zmiany $\mathrm{w}$ jego otoczeniu. W odniesieniu do osób z dysfunkcją wzroku rozwój nowych technologii umożliwia po raz pierwszy korzystanie z niezależności w zdobywaniu informacji i pełniejsze uczestnictwo w życiu społecznym. Stwarza szansę na uniknięcie niepełnosprawności lub znaczne ograniczenie jej skutków. Celem prezentacji jest przedstawienie najnowszych osiągnięć naukowych dotyczących edukacji, diagnostyki i rehabilitacji osób z dysfunkcją wzroku.

Słowa kluczowe: nowe technologie, edukacja, rehabilitacja, wzrok

\section{Wstęp}

Postęp naukowy i związane z nim pojawianie się nowych dziedzin nauki sprawiają, że stale aktualne i - może nieco prowokujące - pozostaje pytanie o definicję tego terminu. Szczególnie jest to widoczne w odniesieniu do nauk biologicznych, łączących się z technologią. Wątpliwość, co można uznać w nauce za postęp, a co nim na pewno nie jest, prowadzi do zniekształcenia pierwotnego znaczenia, które stanowi o istocie postępu, a w dalszej konsekwencji do działań sprzecznych z dobrostanem człowieka.

Zasadniczym warunkiem działania czy projektu aspirującego do miana naukowego jest relacja do podstawowych dóbr ludzkich - czy je pomnaża i buduje, czy też je ogranicza lub wręcz niszczy.

Codzienność stale dostarcza argumentów, że postęp cywilizacyjny przynosi niezaprzeczalne korzyści, jakimi są poprawa komfortu życia, dynamiczny rozwój nauk czy narodziny społeczeństwa informacyjnego, ale równocześnie generuje także efekty niekorzystne. Konsekwencją technicyzacji życia współczesnego 
człowieka są bowiem nadmierny pośpiech, wzrost tempa życia, zagrożenie dla zdrowia psychicznego i fizycznego, wzrost chorób cywilizacyjnych, np. układu sercowo-naczyniowego: nadciśnienia tętniczego, choroby niedokrwiennej serca, a ponadto schorzeń o wymiarze globalnym: otyłości, cukrzycy, zwyrodnienia plamki żółtej związanego z wiekiem (AMD), jaskry i katarakty (Dycht 2012).

Postęp cywilizacyjny niesie więc ze sobą nieuniknioną sprzeczność... Z jednej strony, umożliwia pokonanie nieuleczalnych dotąd chorób, a $z$ drugiej, powoduje pojawienie się nowych schorzeń (zagrożeń), z którymi muszą sobie radzić rozwijające się społeczności. Postępowi współczesnej medycyny, doskonaleniu diagnostyki trudności rozwojowych i niwelowaniu etiologii niepełnosprawności towarzyszy, niestety, częściej występujące wcześniactwo, coraz późniejsze macierzyństwo i postępujące starzenie się społeczeństw (por. Krause 2009).

Niepełnosprawność była i będzie udziałem ludzkości. Dowodzi tego stale wzrastająca współcześnie populacja osób doświadczających problemów ze wzrokiem. Co roku kolejne 1-2 mln ludzi traci wzrok. W 2002 roku Światowa Organizacja Zdrowia alarmowała, że na świecie na początku nowego stulecia $161 \mathrm{mln}$ ludzi (2,6\% populacji) miało problemy ze wzrokiem (WHO 2002): 1,4 mln (o,8\%) stanowiły dzieci poniżej 15. roku życia; $27,6 \mathrm{mln}(17,2 \%)$ - osoby pomiędzy 15 . i 50. rokiem życia; $132 \mathrm{mln}(82 \%)$ - osoby powyżej 50. roku życia. Obecne dane tej organizacji wskazują (WHO 2011), że mamy prawie 300 mln osób z niepełnosprawnością wzroku, w tym ok. 39 mln niewidomych. Jeśli najbliższe lata nie będą skutkować właściwym postępowaniem profilaktycznym, to zgodnie z prognozami w roku 2020 liczba osób niewidomych wzrośnie do $75 \mathrm{mln}$ (Raport AMDAI 2010).

Blisko 90\% osób z niepełnosprawnością wzroku zamieszkuje kraje rozwijające się. W Unii Europejskiej na każde tysiąc mieszkańców cztery osoby to niewidomi lub słabowidzący. Szacuje się, że w 2030 roku co czwarty Europejczyk będzie w wieku emerytalnym, a wśród osób starszych liczba niepełnosprawnych wzrokowo potraja się z każdym dziesięcioleciem ich życia (Wapiennik, Piotrowicz 2002, s. 65).

Powyższe dane epidemiologiczne wskazują wyraźnie, że wiodącymi przyczynami stałego zwiększania się całkowitej liczby osób niewidomych i słabowidzących są starzenie się społeczeństw oraz niepełnosprawność wzrokowa związana z wiekiem, a z drugiej strony, postęp i rozwój nauk medycznych i psychologicznych (szczególnie ich działów z pogranicza pedagogiki specjalnej: pediatrii, neurologii, okulistyki, otolaryngologii, psychologii klinicznej, psychologii rehabilitacyjnej), które, ratując życie, nie potrafią wyeliminować wszystkich skutków chorób, wypadków itp.

W skali globalnej wzrasta liczba dzieci słabowidzących i równocześnie maleje liczba całkowicie niewidomych - w wyniku upowszechniania opieki lekarskiej i wczesnej interwencji wobec małych dzieci z problemami wzroku, a także szeroko pojętej opieki społecznej nad osobami dorosłymi i starszymi z problemami wzroku, co warunkuje rozwój diagnostyki zaburzeń rozwojowych. 
Obserwując zmiany, jakie zachodzą w populacji osób z dysfunkcją wzroku, można dostrzec również tendencję do zwiększania się liczby dzieci, u których poza uszkodzeniem (lub brakiem) wzroku występują jeszcze innego rodzaju zaburzenia i deficyty rozwojowe (np. niepełnosprawność intelektualna, zaburzenia mowy, schorzenia neurologiczne, brak słuchu) - zarówno na świecie, jak i w Polsce zwiększa się liczba dzieci niewidomych i słabowidzących z dodatkowo ograniczoną sprawnością.

Oddzielną grupę stanowią osoby, u których poważne zaburzenia widzenia lub utrata wzroku są związane z procesem starzenia; często towarzyszą temu dodatkowe dolegliwości: katarakta starcza (na skutek zmiany składu fizycznego i chemicznego soczewki), zwyrodnienie plamki żółtej (za przyczyną degeneracji starczej organizmu), jaskra w starszym wieku (np. w wyniku stosowania niektórych leków), cukrzyca starcza (z powodu zmian miażdżycowych trzustki). Statystyki wykazują wyraźną tendencję do zwiększania się tej populacji. „Dynamicznie postępujący wzrost średniej długości życia ludzkiego uznaje się za znaczący sukces medycyny. Wydłużenie go kosztem rozciągnięcia w czasie okresu starości naznaczonej piętnem chronicznych chorób i niepełnosprawności, stanowi o jej porażce" (Kilian 2011, s. 368).

W Polsce obserwuje się wzrost problemów związanych ze wzrokiem zarówno u dzieci, jak i u osób starszych. U dzieci w wieku szkolnym pojawia się coraz wyraźniejsza tendencja rozwoju wad wzroku (nadwzroczności, krótkowzroczności). Ok. 40\% młodzieży wymaga korekcji okularowej. Dodatkowo istnieje jeszcze grupa dzieci i młodzieży, która choć nie podlega korekcji okularowej, to jednak widzi nieprawidłowo. Statystyki GUS (2004) odnotowują, że 941 tys. osób ma bardzo poważne ograniczenia widzenia. Przewiduje się, że do 2020 roku liczba osób po 85. roku życia wzrośnie dwukrotnie, przez co również problematyka wad wzroku będzie obejmować coraz większą część społeczeństwa.

Rosnąca na całym świecie populacja osób z problemami wzroku z jednej strony, a z drugiej gwałtowny postęp technologiczny, który odciska swe piętno na sytuacji edukacyjnej, zatrudnieniu, codziennym bytowaniu i funkcjonowaniu społecznym osób niewidomych i słabowidzących, nakazują stawiać pytania, w jakich okolicznościach postęp ten rzeczywiście służy człowiekowi z problemami widzenia, a kiedy pozostaje w sprzeczności z jego podstawowymi dobrami.

\section{Zastosowanie nowoczesnej techniki i technologii komputerowej we wspomaganiu edukacji osób niewidomych i słabowidzących formą przezwyciężania wykluczenia cyfrowego}

Obecne czasy charakteryzuje technologiczna rewolucja. Powszechnie stosowane komputery stają się nieodzownym elementem nowoczesnej edukacji. Jednakże dla osób z dysfunkcją wzroku ten technologiczny postęp to coś więcej niż tylko urozmaicenie, wzbogacenie zasobów narzędzi edukacyjnych... To: niezależność w zdobywaniu informacji i możliwość pełniejszego uczestnictwa w procesie 
edukacyjnym - poza szkolnictwem specjalnym - w ramach kształcenia integracyjnego i włączającego.

Dzięki specjalistycznemu oprogramowaniu i oprzyrządowaniu osoby z uszkodzeniem wzroku stają się równoprawnymi użytkownikami sprzętu informatycznego i sieci internetowej (Ossowski, Muszalska 2007, s. 166). Nowoczesne technologie informatyczne dają swobodę w pozyskiwaniu informacji, jej przetwarzaniu oraz twórczej pracy nad tekstem i grafiką.

Nauczanie wspomagane komputerowo odgrywa coraz większą rolę w tyflodydaktyce, umożliwiając w sposób naturalny indywidualizację kształcenia - ze względu na dostosowanie treści, formy i tempa kształcenia do różnic między uczniami wynikających m.in. ze stosowanych materiałów dydaktycznych i posiadanych możliwości wzrokowych (Niemierko 2007, s. 129).

Współczesne stanowisko komputerowe dla osoby niewidomej to już nie tylko komputer (PC), ale również screen reader - oprogramowanie umożliwiające rozpoznawanie zawartości monitora (ikony, paski narzędzi, tekst): Fine Reader, FineReader Professional, Cicero Text Reader, KNFB Reader; syntezator mowy umożliwiający dźwiękowe odcztywanie zawartości pokazanej na ekranie komputera (Loquendo, Speak II, SynTalk, IVONA, Dant, eSpeak, RealSpeak, Sapi 5); monitor brajlowski (linijka brajlowska) - przystawka umożliwiająca odczytywanie w brajlu zawartości ekranu komputera (np. Braille Voyager, Braille Focus, Vario); skaner, który pozwala przekształcić drukowane teksty z wersji graficznej na tekstową; notatnik brajlowski do sporządzania notatek, odsłuchiwania książek, plików $\mathrm{MP}_{3}$, z syntezą mowy (Braille Sense lub PAC Mate); drukarka brajlowska do drukowania tekstów w piśmie brajlowskim oraz wypukłej grafiki (ViewPlus, Everest, Index).

Nowoczesny sprzęt adaptacyjny umożliwia korzystanie z pisma brajla przez ucznia i jego nauczyciela bez konieczności opanowywania tego systemu przez pedagogów. Stwarza możliwość zapisu i odczytywania informacji w formacie dostępnym tak dla osób z dysfunkcją wzroku, jak i dla prawidłowo widzących. Stanowi tym samym ważne udogodnienie w procesie włączania ucznia w system szkolnictwa powszechnego ${ }^{1}$. Są to:

- Programy optycznego przetwarzania tekstu czarnodrukowego na system brajla (Optical Character Recognition - OCR). Do przetworzenia zwykłej drukowanej książki na równoważny zapis w systemie brajla potrzebny jest zestaw, czyli: skaner z oprogramowaniem OCR, komputer, program konwersji na system brajla i drukarka brajlowska.

- Programy optycznego rozpoznawania pisma brajla (Optical Braille Recognition - OBR). Służą do przetworzenia brajla na pismo czarnodrukowe drukowane (chociaż znaki brajlowskie mają taki sam kolor jak ich tło, to

${ }^{1}$ Szerzej na ten temat: Czerwińska 2005; Jakubowski 2001; Laszkowska 2005; Wiazowski 2009, 2001. 
jednak przy skanowaniu rzucają delikatne cienie, które wykorzystuje się do zlokalizowania punktów). W tym przypadku używa się dokładnie takiego samego zestawu urządzeń jak w przypadku przetwarzania pisma drukowanego na alfabet brajla - skanera $\mathrm{z}$ oprogramowaniem OBR, komputera, programu do konwersji i drukarki czarnodrukowej. Osoby widzące mogą odczytywać teksty utrwalone w brajlu bez potrzeby uczenia się tego. Osoby niewidome otrzymują narzędzie do powtórnej edycji, przedruków i przechowywania brajlowskich oryginałów, które łatwo ulegają zniszczeniu.

Swoistą rewolucję w tyflodydaktyce stanowi wypukła grafika dla niewidomych, a zwłaszcza urządzenia przekształcające pismo drukowane na postać do odbioru zmysłem dotyku: Zy-Fuse - urządzenie fototermiczne do uwypuklania wydrukowanych obiektów graficznych, wymagające umiejętnego dobrania parametrów czerni i odcieni szarości przy opracowywaniu rysunku do obróbki termicznej; Optacon urządzenie, które przetwarza pojedynczy znak graficzny na jego wypukły obraz (wypukły obraz powstaje na wibracyjnym ekranie dotykowym).

Równie nowatorskim rozwiązaniem technicznym, zwłaszcza w tyflografice, są urządzenia służące do sporządzania wypukłych rysunków z zastosowaniem pęczniejącego papieru lub pęczniejącej farby - np. Thermo Pen do pisania i tworzenia wypukłych obrazów bezpośrednio na specjalnym papierze pęczniejącym. Wypukłe ilustracje są wykonywane metodą termoformowania próżniowego. Coraz większym zainteresowaniem osób z dysfunkcją wzroku cieszą się urządzenia do uzyskiwania tzw. mówiącej grafiki (np. udźwiękowionej grafiki dotykowej, jak w Tactile Talking Tablet) czy służące do czytania z zastosowaniem mowy syntetycznej - Auto-Lektor, Multilektor.

Nowe technologie komputerowe są obecnie jednym z podstawowych determinantów efektywnego kształcenia uczniów niewidomych i słabowidzących np. we Francji. W ramach eksperymentalnego projektu wprowadzonego w siedmiu szkołach dzięki nowoczesnym udogodnieniom techniki umożliwiono dzieciom z dysfunkcją wzroku uczestniczenie w tych samych zajęciach co ich prawidłowo widzący rówieśnicy. Celem francuskiego systemu edukacyjnego jest wyeliminowanie podręczników szkolnych i zastąpienie ich przenośnymi komputerami zawierającymi podręczniki elektroniczne oraz umożliwiającymi dostęp do internetu, by za jego pośrednictwem odbierać ćwiczenia przesyłane przez nauczyciela i odsyłać odrobione zadania. Są to:

- komputer-tornister elektroniczny;

- tablica elektroniczna (nauczyciel wyświetla na białej tablicy zawartość ekranu komputera i na niej pracuje, zmiany zapisując w komputerze; może bezpośrednio wejść do komputerów uczniów podłączonych do sieci; system usprawnia pracę bezpośrednią z uczniami niewidomymi, jeśli tylko dostępne są odpowiednio przygotowane komputery);

- system MINIO (uzupełnienie tablicy elektronicznej; bezpośrednio na tablicy zapisje się flamastrem tekst, a urządzenie w postaci linijki przytwierdzonej 
z boku rejestruje go i przesyła do połączonych komputerów na zasadzie wiernego odtworzenia; ponieważ następuje konwersja pisma odręcznego na drukowane, wymaga to bardzo starannego pisania na tablicy, by uniknąć nieprawidłowej interpretacji liter).

Bez nowoczesnych technologii informatycznych ludzie pozbawieni możliwości prawidłowego widzenia szybko zostaliby wykluczeni społecznie. Ich marginalizacja niechybnie stałaby się faktem. Technicyzacja życia współczesnego społeczeństwa wymusza na jego członkach nowe procesy adaptacji, które warunkują z kolei satysfakcjonujące życie społeczne - tak w wymiarze jednostkowym, jak i grupowym.

\section{Biotechnologia i inżynieria genetyczna - szansa czy zagrożenie dla rozwoju człowieka z dysfunkcją wzroku?}

Wiek XX przyniósł zainteresowanie człowiekiem, jego potrzebami i możliwościami. Zogniskował aktywność społeczną na działaniach pomocowych na rzecz osób potrzebujących wieloaspektowego wsparcia. Zweryfikował dotychczasowe poglądy i doprowadził do zmiany postaw wobec osób słabszych, odmiennych, odbiegających od powszechnie przyjętej psychofizycznej normy. W dalszej konsekwencji zapoczątkował zmiany jakościowe w zakresie form i charakteru wspomagania społecznego, a zwłaszcza potrzeb rehabilitacyjnych, edukacyjnych, prawnych, pomocowych osób z niepełną sprawnością organizmu i środowisk ich bytowania $\mathrm{z}$ akcentem na edukację integracyjną i włączającą, zatrudnienie na otwartym rynku pracy, uznanie prawa tych osób do samostanowienia i samorealizacji.

Kolejne stulecie zdaje się jednak zaprzeczać (przynajmniej częściowo) tym uznawanym dotychczas wartościom i obowiązującym normom. Oferowane przez różne nauki i nowatorskie technologie możliwości zaczynają zmieniać (lub już zmieniają) świat człowieka oraz dokonują radykalnych zmian w jego naturze.

Przejawem nowego podejścia w myśleniu o przyszłych drogach rozwoju człowieka jest transhumanizm, opisywany przez jednych jako filozofia, którą należy rozwinąć fizycznie, mentalnie i społecznie przy użyciu racjonalnych metod (Sandberg, Bostrom 2008), przez innych jako badanie konsekwencji, obietnic i potencjalnych zagrożeń wynikających z użycia nauki, techniki i innych środków twórczych, mających na celu przezwyciężenie podstawowych ludzkich ograniczeń, a przez jeszcze innych jako ruch intelektualno-kulturowy, pozytywnie odnoszący się do możliwości i potrzeby fundamentalnej zmiany ludzkiej kondycji, zwłaszcza wykorzystania technologii do wyeliminowania procesu starzenia się oraz udoskonalenia intelektualnych, fizycznych i psychicznych możliwości człowieka (za: Zaorska 2014, s. 486).

Transhumanizm można więc rozumieć jako zgodę na poprawę ludzkiej kondycji poprzez ulepszające ciało technologie, skutkujące wyeliminowaniem starzenia się i rozszerzeniem możliwości umysłowych i fizycznych człowieka (cyborgizacja), oraz jako studia nad etyczno-społecznymi konsekwencjami implementacji 
tych technologii (Hughes 2004). W odróżnieniu od humanizmu chodzi nie tylko o przyzwolenie, ale wręcz o oczekiwanie na radykalne zmiany w naturze ludzkiej. Stąd poparcie dla najnowszych technologii: nanotechnologii, biotechnologii czy technologii informacyjnych i hipotetycznych technologii przyszłości (jak np. sztuczna inteligencja, transfer umysłu, krionika).

Przedstawiciele transhumanizmu: Mikołaj Fiodorow, Ferejdun M. Esfandiary, Max More, Anders Sandberg, Robin Hanson, głoszą, że filozofia ta - dzięki zastosowaniu innowacji w postaci inżynierii genetycznej, nanotechnologii molekularnej, neurofarmaceutyków, sztucznej inteligencji, substancji regulujących samopoczucie i poprawiających pamięć, terapii przeciw starzeniu się czy ulepszaniu protez - umożliwi wykorzystanie światowego potencjału wiedzy dla poprawy bytu ludzkości. Wykorzystując w działaniu rozum, osiągnięcia nauki i technologię, uda się, według transhumanistów, wyeliminować biedę, niepełnosprawności czy niesprawiedliwości społeczne, poprawić znacząco jakość życia istot żywych na ziemi i zapewnić społeczną równość w dostępie do dóbr materialnych (Nate 2012, s. 201-202; Young 2006).

W koncepcję transhumanistyczną efektywnie wpisuje się poszerzanie możliwości ciała człowieka za pomocą protez. Dzięki postępowi nauk technicznych i medycznych osoby z niepełnosprawnością mogą lepiej funkcjonować i pełniej rozwijać swoje możliwości. Znamy już implanty ślimakowe, słyszymy o coraz sprawniejszych protezach kończyn, przeszczepach narządów. Przeprowadza się również przeszczepy rogówki. Ponadto trwają zaawansowane prace nad biookiem. Naukowcy poinformowali o wyhodowaniu w warunkach laboratoryjnych części oka. Japońscy badacze posłużyli się w tym celu komórkami macierzystymi niepochodzącymi z ludzkich embrionów. Pobudzili je do przekształcania się w komórki siatkówki. Autorem badań jest Yoshiki Sasai z Centrum Biologii Rozwojowej RIKEN w Kobe.

Wydaje się, że o oku ludzkim wiadomo już wszystko. Jednak dopiero niedawno wykryto, że ma ono potencjalną zdolność do regeneracji uszkodzonej siatkówki. Zawdzięcza ją komórkom macierzystym, a więc takim, które mogą przekształcić się w dowolną tkankę organizmu (dotychczas uważano, że w oku nie ma komórek tego typu).

Narząd ten jest bardzo złożonym mechanizmem, wykształconym w toku ewolucji. Starzeje się jako jeden z pierwszych organów ludzkiego ciała. Efektem tego procesu jest m.in. zaburzenie funkcjonowania mięśnia rzęskowego, skutkujące złym napięciem akomodacji obserwowanym po 40. roku życia. Innym efektem starzenia się narządu wzroku, a dokładniej siatkówki oka, mogą być toksyczne odpady, które oko niczym fabryka chemiczna, wykorzystując ogromne zasoby energii, produkuje i zbiera w przypominających beczki kroplach tłuszczowych. Te toksyczne złogi gromadzą się w nabłonku barwnikowym jako tzw. lipofuscyny. Głównym składnikiem tych pozostałości jest cząsteczka A2E (składem chemicznym przypominająca witaminę A). W najbliższej przyszłości będą one poddane 
wnikliwej analizie różnicującej w celu ustalenia ich wpływu na proces starzenia się oka.

Jednak aby dostać się do narządu tak złożonego i wrażliwego jak oko, trzeba stosować najnowocześniejsze technologie ${ }^{2}$. Dzięki pogłębionym badaniom idea sztucznego oka o bardzo dużej dokładności przekazu staje się coraz bardziej realna. Naukowcy potrafią już stworzyć protezę tego narządu, w której sygnał z kamery przetwarzany jest na impulsy elektryczne i transmitowany za pomocą elektrod do komórek siatkówki. Impulsy te przesyłane są potem do mózgu i interpretowane jako obraz. Sygnał z pojedynczej elektrody pobudza naraz kilka tysięcy komórek nerwowych siatkówki, tzw. komórek zwojowych (Kowalczyk, Wojtkowski 2006). A więc dokładność przekazywanego obrazu nie jest na razie duża, w efekcie czego informacja, która trafia z oka do mózgu, nie jest zbyt szczegółowa, a rozdzielczość widzenia jest niewielka. Oznacza to w praktyce, że osoba niewidoma - dzięki implantowi - może zlokalizować wzrokowo obiekt, lecz jej mózg dopiero po kilkudziesięciu sekundach oglądania go potrafi zinterpretować nieprecyzyjny jeszcze sygnał z protezy oka (Burduk i in. 2008).

Z coraz większą precyzją pobudza się komórki oka (Szkaradek i in. 2013). Polskoamerykański zespół naukowców (uniwersytety Stanforda oraz Kalifornijski i krakowska $\mathrm{AGH}^{3}$ ) bada właśnie, jak pobudzać je intensywniej. Uczeni mają nadzieję, że dzięki temu w przyszłości da się opracować implant, który pozwoli osobom niewidomym zobaczyć świat z nieosiągalną wcześniej dokładnością. Trzeba jedynie rozszyfrować „język”, w jakim oko komunikuje się z mózgiem (Tomala 2014). By w przyszłości implanty pozwalały na bardziej szczegółowe widzenie, konieczne jest również zastosowanie znacznie mniejszych elektrod i zwiększenie ich liczby na siatkówce z kilkudziesięciu do kilku tysięcy. Poza tym badacze chcą, by impulsy z jednej elektrody były bardzo precyzyjne i docierały do pojedynczych komórek zwojowych, a nie do tysięcy naraz (Wojtkowski 2009).

Do rozpoznawania tak złożonego obrazu, z jakim ma do czynienia ludzkie oko, potrzeba nawet 20 różnych typów komórek zwojowych - odpowiedzialnych za

2 Na Uniwersytecie Mikołaja Kopernika w Toruniu dr hab. Maciej Wojtkowski, jako pierwszy na świecie, wraz z kierowanym przez siebie zespołem rozwija nowe techniki badania czynności struktury oka ludzkiego. Skonstruował tomograf optyczny do obrazowania siatkówki za pomocą tomografii optycznej SOCT. Projekt „Opracowanie nowoczesnych technik optycznych do obrazowania struktury i czynności oka ludzkiego” jest realizowany w ramach programu TEAM Fundacji na rzecz Nauki Polskiej. Badanie aktywności siatkówki jest możliwe od lat 90. dzięki wykorzystaniu niebieskiego światła, stanowi ono jednak duży dyskomfort dla pacjenta, który przez moment praktycznie nie widzi niczego poza białą plamą. Nowa metoda pozwala w wysokim stopniu zredukować niedogodności związane ze zbyt silną mocą emitowanego światła, a jednocześnie otrzymywać dobrej jakości obrazy.

3 Dr Paweł Hottowy z Wydziału Fizyki i Informatyki Stosowanej Akademii Górniczo-Hutniczej. Udział zespołu z AGH w tych badaniach finansowany jest w ramach programu HARMONIA Narodowego Centrum Nauki. Naukowcy z AGH stworzyli też właśnie pierwszy w Polsce sztuczny neuron. 
przetwarzanie i wysyłanie do mózgu informacji o kolorze, ruchu itp. W procesie tym pobudzane są równocześnie różne typy komórek siatkówki, następnie komunikują się one z mózgiem, który otrzymuje w jednej chwili różnorodne informacje.

Rozpoznawanie tak precyzyjnego „kodu” oko - mózg wymaga usprawnienia impulsów przesyłanych za pomocą elektrody do komórki siatkówki. Naukowcy pracują nad odtworzeniem impulsów elektrycznych, za pomocą których różne komórki siatkówki komunikują się z mózgiem, i przekazaniem ich do odpowiedzialnych za te sygnały komórek.

Obecnie prowadzone badania - na siatkówkach makaka ${ }^{4}$ - pozwalają na powtórzenie i precyzyjnie przekazanie impulsów niezależnie około 10 sąsiadującym ze sobą komórkom zwojowym (Rozpędek 2014). Uczeni pracują nad tym, by możliwe było dostarczanie informacji niezależnie dwóm typom komórek zwojowych - komórkom parasolowatym (odpowiedzialnym za rozpoznawanie ruchu i obrazów o niskim kontraście) i komórkom karłowatym (umożliwiającym rozpoznawanie kolorów i szczegółów). Te dwa typy stanowią około 70\% wszystkich komórek zwojowych w oku ludzkim. Stymulowanie ich umożliwi skonstruowanie bardzo precyzyjnego implantu. Wówczas mózg „zobaczy” obraz na tyle ostry, by możliwe było wyraźne widzenie koloru, a nawet czytanie. Skonstruowanie takiego sztucznego oka jest coraz bliżej. Urządzenia przekształcające obraz tak, by mogli go odczytać niewidomi (implanty mikroelektrodowe), będą miały zastosowanie zwłaszcza u osób ze schorzeniami neurodegeneracyjnymi wzroku (np. zwyrodnieniem plamki żółtej).

Jednakże z drugiej strony wyższe zdolności nawigacyjne, jakie osiągniemy, gdy w oku ludzkim umieszczony zostanie komputer, sprawią, że człowiek - niczym cyborg - dzięki miniaturowym soczewkom będzie dysponował nadnaturalnym wzrokiem. W debatach dotyczących transhumanistycznych technologii i tendencji podkreśla się, że dzięki postępowi nauk osiągniemy wiele oczekiwanych korzyści, jak np. poprawę długości życia, dostęp do służby zdrowia o odpowiedniej jakości. Wysiłki na rzecz podnoszenia inteligencji przyniosą pozytywne konsekwencje w postaci lepszej edukacji, racjonalnego zarządzania i efektywniejszej wymiany informacji. Ulepszenia komunikacyjne, strategie zarządzania rynkiem wypromują pokojowe rozwiązania konfliktów między narodami.

Jednym z postulatów transumanizmu jest stworzenie profilaktyki i diagnostyki medycznej, która ograniczy zbyt szybki wzrost populacji, odpowiedzialny za przeludnienie i biedę świata, i będący poważnym problemem ludzkości. Ten system medycyny już ulega intensywnym przeobrażeniom.

Znaczący skok cywilizacyjny ostatniego stulecia sprawił, że osiągnięcia świadczące o poziomie rozwoju i służące dokonywaniu kolejnych wielkich odkryć

${ }^{4}$ Badacze oświetlają je i badają sygnał elektryczny, jaki oko generuje w odpowiedzi na ten bodziec. Następnie za pomocą stymulacji elektrycznej próbują odtworzyć w komórkach dokładnie taki sam sygnał. 
znajdują się w opozycji do pierwotnych potrzeb człowieka. W dyskusji nad etycznymi aspektami stosowania biotechnologii, obok niewątpliwych korzyści dla rozwoju i funkcjonowania człowieka, mówi się również o wątpliwościach, czy tego typu dążenia nie prowadzą do augmentacji czy cyborgizacji człowieka (Maciąg, Kałafut 2011).

Czy nieinwazyjne badania prenatalne nie staną się pewnym rodzajem selekcji, a nawet eugeniki P (eugeniki pozytywnej), polegającej na wspieraniu rozmnażania jednostek posiadających tzw. dobre geny (Walter 2006)? Powszechne stosowanie badań prenatalnych oraz możliwość wykrywania coraz większej liczby cech dziedzicznych, w tym podatności na schorzenia o późnym czasie wystąpienia objawów, skłaniają do refleksji nad konsekwencjami i kierunkiem rozwoju współczesnej genetyki medycznej. Mamy do czynienia ze zjawiskiem powolnego wzrostu akceptacji dla coraz bardziej wątpliwych etycznie technik biomedycznych, w których życie ludzkie poddawane jest kryteriom utylitarnym (Tamborska-Zedlewska 2004). Zjawisko to nosi nazwę tzw. etycznej równi pochyłej (za: Żekanowski 2003, 2001). Jednym z przykładów takiego podejścia jest eugenika.

Dopiero niedawno osoby z niepełnosprawnością, ludzie z wrodzonymi wadami wywalczyli sobie prawo do pełnego uczestniczenia w życiu społecznym, a już zaniepokojenie budzi perspektywa powrotu otwartej eugeniki. Pojawiają się głosy - wcale nie jednostkowe - zupełnie otwarcie opowiadające się za ideami eugenicznymi. Jednym z przykładów może być stanowisko profesora Dana W. Brocka, bioetyka z Zakładu Bioetyki Klinicznej Narodowych Instytutów Zdrowia w Bethesda, który twierdzi, że społeczeństwo mogłoby mieć się lepiej, gdyby nie dopuszczało do narodzin dzieci niewidomych i poważnie upośledzonych (za: Żekanowski 2003). Odwołując się do eugeniki poprzednich stuleci, używa on argumentu o zapobieganiu cierpieniu rodziców poprzez niedopuszczanie do urodzenia dzieci chorych (decyzja o narodzinach dziecka powinna pozostawać w gestii rodziców, a nie rządu). Dan W. Brock uważa, że mimo wysiłków jakość życia ludzi z niepełnosprawnością nie odpowiada jakości życia osób w pełni sprawnych. Idee eugeniczne wzmacniać mają - jego zdaniem - argumenty ekonomiczne: ograniczenie liczby osób niepełnosprawnych może zmniejszyć zasięg programów rehabilitacyjnych, a więc jednocześnie będą na nie potrzebne mniejsze nakłady.

Dodatkowo dla coraz większej grupy przyszłych rodziców wygodnym rozwiązaniem, niwelującym ryzyko urodzenia dziecka chorego lub obarczonego niepełnosprawnością, staje się diagnostyka prenatalna. Jej zwolennicy wskazują nawet, że pozwala ona uniknąć aborcji w przypadku nieplanowanej ciąży w rodzinach wysokiego ryzyka (zob. Biesaga 2008).

Poradnictwo prenatalne jest też zdaniem wielu niezbędne w przypadku schorzeń skutkujących śmiercią $\mathrm{w}$ dzieciństwie albo powiązanych z nieusuwalnym bólem i cierpieniem dziecka. Należy jednak w tym miejscu podkreślić, że ocena poziomu cierpienia człowieka nigdy nie będzie obiektywna. Nie wiadomo również, kto miałby jej dokonywać. Umożliwienie eliminacji chorób genetycznych, takich jak 
mukowiscydoza (Bal, Sobczyńska-Tomaszewska 2004) czy hemofilia, sprawi, że będzie można w prosty sposób przejść do usuwania innych odmienności rozwojowych o etiologii genetycznej, mniej lub bardziej niepożądanych społecznie: krótkowzroczności, daltonizmu, otyłości, alkoholizmu, ADHD, odmienności seksualnych. I tak, niepostrzeżenie, eugenika negatywna przejdzie w genetyczne projektowanie ludzi, czyli eugenikę pozytywną. Jak twierdzi Cezary Żekanowski (2003): „Wraz z rozwojem diagnostyki molekularnej, z wprowadzeniem mikroprocesorów DNA, możliwe stanie się bardzo szybkie i ekonomicznie opłacalne przeglądanie całego genomu człowieka w poszukiwaniu bardzo wielu mutacji uznanych za szkodliwe lub niepożądane. Możliwe do realizacji stają się marzenia o znaczącym zmniejszeniu obciążenia puli genowej mutacjami, na przykład poprzez zastosowanie na szeroką skalę technik zapłodnienia pozaustrojowego i diagnostyki preimplantacyjnej”. Tak rodzi się eugenika konsumencka.

Terapię genową, dopuszczającą ulepszanie cech fizycznych dzieci w zależności od potrzeb, uznaje coraz więcej ludzi. Ich stanowisko buduje zaś kultura masowa, zbieżna z procesem „macdonaldyzacji” społeczeństwa. Już teraz coraz więcej instytucji wspomagających rozród jest bardziej zainteresowanych udzielaniem pomocy w urodzeniu dziecka wolnego od niektórych recesywnych mutacji niż samym wspieraniem par w urodzeniu dziecka. Wybór profilu genetycznego przez przyszłych rodziców nie wydaje się tak nierealny, skoro możliwe jest już eliminowanie w ten sposób najczęstszych szkodliwych mutacji, skutkujących chorobami monogenowymi czy predyspozycją do niektórych schorzeń, np. nowotworowych.

Czy w perspektywie selekcji najlepszych embrionów dziecko jest niepowtarzalnym darem, czy niespodzianką? Jak postrzegać je jako osobę z prawem samostanowienia, gdy w myśl nieograniczonej „eugeniki wolnego rynku” jest jedynie rezultatem wyboru rodziców, uzależnionego od mody, aspiracji, sytuacji ekonomicznej rodziny?

\section{Przyszłe drogi rozwoju tyflopedagogiki}

Jeśli człowiek - zgodnie z wizją transhumanizmu - stanie się istotą powstałą z kombinacji struktur biologicznych i mechanicznych, dysponującą nieporównywalnie szybszą i wyższą inteligencją niż teraz, zdolną do posiadania większego potencjału i bardziej kreatywną, niepodlegającą fizycznemu procesowi starzenia się i chorobom, czy będzie to oznaczać koniec ludzkości we współczesnym jej rozumieniu (zob. Fukuyama 2004)?

Czy w przyszłości będzie istniała w ogóle potrzeba działań o charakterze specjalnym? Czy mamy do czynienia z nieuchronnie postępującą marginalizacją wspierającej roli tyflopedagogów? Amadeusz Krause (2009, s. 22; zob. też Gołubiew-Konieczna, Krause 2008) opisuje deprecjację roli zawodowej pedagogów specjalnych pracujących z dziećmi z niepełnosprawnością w stopniu lekkim, zapytując: „Czy to już koniec pedagogiki specjalnej?”, „czy ta dyscyplina straci sens swojego 
istnienia, pomocy i wspierania ludzi z różnymi trudnościami rozwoju?’. Marzenna Zaorska (2014, s. 496) rysuje pesymistyczną wizję przyszłości pedagogiki specjalnej: „będzie [ona] bardziej potrzebna w jednych obszarach, a mniej lub wcale w innych, by ostatecznie stać się w ogóle niepotrzebną". Stanowisko swoje autorka formułuje na podstawie zmian, jakie wyznaczają obecne i przyszłe tendencje w rozwoju społeczno-cywilizacyjnym i naukowo-technicznym: zainteresowanie stanem chorobowym i jego etiologią (zgłębianie anatomii ludzkiego organizmu, funkcji poszczególnych narządów i ich ewentualnych uszkodzeń) oraz możliwościami terapii służących poprawie somatycznego stanu człowieka. Ten obszar działań ukierunkowuje na profilaktykę medyczną i wyspecjalizowaną terapię wykorzystującą osiągnięcia nauki i techniki, w tym przeszczepiania narządów i wszczepiania sztucznych elementów (augmentacja). Marzenna Zaorska (tamże, s. 497) przewiduje, że w niedługim czasie wyeliminowany zostanie problem niepełnosprawności sensorycznych i ruchowych, a dzięki rozwojowi nauk genetycznych dojdzie do rozwiązania kwestii niepełnosprawności uwarunkowanej genetycznie. W dalszej perspektywie zostaną zminimalizowane, a ostatecznie wyeliminowane niepełnosprawność intelektualna oraz poważne schorzenia przewlekłe.

Czy świat wybierze ewolucję ku transczłowiekowi? Czy będziemy dążyć ku doskonałości, nieśmiertelności? Taka wizja przyszłości nie uwzględnia stanu niepełnej sprawności człowieka... (zob. Guzowski 2014). Czy zgoda na postęp naukowy oznacza zmierzch ludzkości w jej współczesnym rozumieniu?

By postęp aspirował do miana naukowego, powinien przyczyniać się do poprawy warunków ludzkiego życia i być zgodny z normami moralnymi. Nauka bowiem tylko wtedy służy człowiekowi, gdy daje mu możliwość panowania nad światem, w którym on żyje. Jeśli nauka stanowi wartość niższą niż sam człowiek, to dobro naukowe nie stoi ponad dobrem człowieka. Nie można poświęcić człowieka dla dobra nauki, tak jak nie można poświęcić wartości wyższej dla wartości niższego rzędu, gdyż byłoby to naruszeniem prawa i porządku moralnego, a z nauki czyniłoby wartość absolutną. Ludzkie życie, zdrowie, integralność psychofizyczna nie mogą podlegać prawom nauki.

Pytanie, co w takim razie można poświęcić i w jakich warunkach. Jeśli projekt aspirujący do miana naukowego skutkował będzie śmiercią człowieka, naruszeniem jego psychofizycznej i duchowej integralności lub doprowadzi do stworzenia takich warunków, które sprawią, że życie człowieka w danej społeczności będzie utrudnione, wówczas taka pseudonaukowa interwencja (a raczej manipulacja) nie może być akceptowana moralnie ani dopuszczana. Dotyczy to również sytuacji, gdy pewne wartości pozostają względem siebie w sprzeczności, np. ratowanie życia odbywa się kosztem integralności psychofizycznej człowieka. Faktem jest uhierarchizowanie podstawowych dóbr ludzkich i usprawiedliwione może być poświęcenie dóbr niższego rzędu na rzecz wartości wyższych. Pomnożenie lub weryfikacja wiedzy naukowej nie stanowią jednak dóbr usytuowanych wyżej niż podstawowe ludzkie dobra - także wówczas, gdy wiedza taka miałaby służyć 
człowiekowi w przyszłości. Gdyby tak miało być, wiedza stałaby się wartością absolutną, a dobrostan ludzi „mniej wartościowych” byłby poświęcany dla dobra „bardziej wartościowych”. Tak się dzieje w przypadku wykorzystywania inżynierii genetycznej i biotechnologii w diagnostyce prenatalnej - jeśli przeprowadzana jest w celu wykrywania nieuleczalnej wady i skutkuje aborcją. Tylko diagnostyka prenatalna stosowana $\mathrm{z}$ założeniem leczenia zaburzeń genetycznych, szukania sposobów ulżenia człowiekowi choremu i jego rodzinie jest moralnie uzasadniona. Wykorzystanie nowoczesnych technologii do poprawy sytuacji edukacyjnej ucznia $z$ dysfunkcją wzroku jest prawomocne z naukowego i moralnego punktu widzenia. Cyborgizacja człowieka, polegająca na zastępowaniu uszkodzonego analizatora wzroku sztuczną protezą, stawiająca go w sytuacji podporządkowania dobrostanu ciała mikroprocesorom, jest etycznie wątpliwa, gdyż tylko pozornie służy dobru człowieka w teraźniejszości i przyszłości. Także główne założenie transhumanistycznej wizji, czyli uformowanie postczłowieka, będącego doskonalszą formą ludzkiej populacji, w której nie ma miejsca dla jednostki mniej sprawnej, niedoskonałej, jest zaprzeczeniem idei postępu naukowego, który - przypomnijmy - stoi w centrum tej ideologii.

Trzeba także wyraźnie podkreślić, że teza transhumanizmu o całkowitym wyeliminowaniu przyczyn niepełnosprawności dzięki osiągnięciom współczesnej medycyny czy techniki brzmi jednak nierealistycznie. Współczesna medycyna umożliwia ratowanie ludzkiego życia - ma za sobą wspaniałe dokonania (podtrzymanie zagrożonych ciąż, ratowanie dzieci przedwcześnie urodzonych, chorych na różnego rodzaju schorzenia, z wadami genetycznymi i wrodzonymi, które do niedawna były śmiertelnym wyrokiem) - dzieciom tym potrzebna jest jednak wczesna i wielodyscyplinarna oraz skoordynowana i ciągła pomoc rehabilitacyjna już od momentu stwierdzenia zaburzenia rozwoju. Postęp w medycynie gwarantuje również wzrost średniej długości ludzkiego życia - kosztem jednak rozciągnięcia w czasie okresu starości, naznaczonej piętnem chronicznych chorób czy niepełnosprawności. W kontekście powyższych uwag i przytoczonych statystyk dotyczących osób z dysfunkcją wzroku należy uznać, że obecnie i w przyszłości rola i zakres wsparcia o charakterze tyflopedagogicznym będą się zwiększać. Zmieniać się będzie jednak charakter tego towarzyszenia - z uwagi na stale rosnącą i zróżnicowaną populację osób z niepełnosprawnością (w tym także wzrokową), a także jej udział w i tak już wysoce skomplikowanym życiu społecznym. Będzie następowało coraz większe otwarcie pedagogów specjalnych (w tym tyflopedagogów) na nowe działania w nowych obszarach opieki i wspomagania rozwoju człowieka, jak choćby: wspieranie rodzin $\mathrm{z}$ dziećmi o odmiennym rozwoju w procesie wczesnej interwencji czy wspieranie rodzin, które potem same założą, doradztwo zawodowe, towarzyszące wsparcie $\mathrm{w}$ dorosłości i starości. Wzrasta zatem aktywność osób z trudnościami rozwoju w życiu publicznym, ale także rośnie zapotrzebowanie na nowe formy wsparcia społecznego, w niespotykanym wcześniej zakresie. 
Współczesny człowiek stoi w obliczu technologicznej rewolucji spowodowanej intensywnym rozwojem nauk, która wymusza coraz szybciej postępujące zmiany w jego otoczeniu. W odniesieniu do osób z dysfunkcją wzroku rozwój nowych technologii umożliwia nieistniejącą dotychczas niezależność w zdobywaniu informacji i pełniejsze uczestnictwo w życiu społecznym. Stwarza również szansę nie tyle na uniknięcie niepełnosprawności, ile na znaczne ograniczenie jej skutków - zwłaszcza w obszarze edukacji, diagnostyki i rehabilitacji. Warunkiem niezbędnym jest jednak to, by te najnowsze osiągnięcia naukowe służyły dobrom podstawowym człowieka.

\section{Bibliografia}

Bal J., Sobczyńska-Tomaszewska A., Czerska K., Obersztyn E., Sands D., Mazurczak T. (2004). Diagnostyka prenatalna mukowiscydozy w rodzinach ryzyka $w$ Polsce: wyniki badań molekularnych. „Medycyna Wieku Rozwojowego”, 8 (3), cz. 2, s. $871-883$.

Biesaga T. (2008). Diagnostyka prenatalna a selekcja eugeniczna. „Życie i Płodność”, nr 2 (4), s. 71-76.

Burduk M., Kałużny J.B., Szkulmowska A., Szkulmowski M., Wojtkowski M., Kowalczyk A. (2008). Spektralna optyczna koherentna tomografia (SOCT) w obrazowaniu pęcherzyków filtracyjnych u pacjentów po trabekulektomii. „Okulistyka”, nr 11 (4), cZ. 1, s. 19-22.

Czerwińska M. (2005). Osoba niewidząca $w$ społeczeństwie informatycznym uwarunkowania i możliwości normalizacji. W: Kosakowski C., Krause A. (red.). Normalizacja środowisk życia osób niepetnosprawnych. Dyskursy pedagogiki specjalnej 4. Olsztyn: Uniwersytet Warmińsko-Mazurski.

Dycht M. (2012). Zagrożenia wzroku człowieka we współczesnym świecie. W: Baraniak B. (red.). Człowiek w pedagogice pracy. Warszawa: Difin.

Fukuyama F. (2004). Koniec człowieka. Konsekwencje rewolucji biotechnologicznej, tłum. Pietrzyk B. Kraków: Znak.

Gołubiew-Konieczna M., Krause A. (2008). Szkolnictwo specjalne - krajobraz po reformie. „Problemy Wczesnej Edukacji”, nr 2 (1), s. 36-45.

Guzowski J. (2014). Transhumanizm - eskapizm czy wizjonerstwo? "Szkice Humanistyczne" (Olsztyn), 14 (1/2), s. 89-105.

Hughes J. (2004). Citizen cyborg: why democratic societies must respond to the redesigned human of the future. Cambridge: Westview Press.

Informacja statystyczna (2004). Warszawa: GUS.

Jakubowski S. (2001). Pomoce dydaktyczne i środki techniczne przydatne w nauczaniu dzieci z uszkodzonym wzrokiem. W: Jakubowski S. (red.). Poradnik dydaktyczny dla nauczycieli realizujących podstawe programowa w zakresie szkoły podstawowej i gimnazjum z uczniami niewidomymi i słabowidzacymi. Warszawa: MEN. 
Kilian M. (2011). Rehabilitacja wobec potrzeb osób w starszym wieku. W: Steuden S., Stanowska M., Janowski K. (red.). Starzenie sięz godnością. Lublin: Wydawnictwo KUL.

Kowalczyk A., Wojtkowski M. (2006). Tomografia optyczna. „Fizyka w Szkole”, nr 52 (2), s. 2-9.

Krause A. (2009). Teoretyczne i empiryczne problemy pedagogiki specjalnej. Zarys obszarów badawczych, „Niepełnosprawność”, nr 1, s. 9-24.

Laszkowska J. (2005). Oddziaływanie gier komputerowych na młodzież. Kraków: nakładem autora.

Maciąg K., Kałafut J. (red.). (2011). Biotechnologia - zagrożenie czy perspektywa rozwoju ludzkości: V Ogólnopolskie Seminarium Studentów Biotechnologii. Kazimierz Dolny nad Wisłą, 21-23 października 2011. Poznań: Studenckie Koło Naukowe Biotechnologów „Mikron”; Sorus Wyd. i Drukarnia Cyfrowa.

Nate S. (2012). The signal and the noise. New York: Penguin.

Niemierko B. (2007). Kształcenie szkolne. Podręcznik skutecznej dydaktyki. Warszawa: WAiP.

Ossowski R., Muszalska M. (2007). Uwarunkowania aktywności zawodowej osób niewidomych i niedowidzacych. Psychologiczna analiza problemu. W: Brzezińska A., Woźniak Z., Maj K. (red.). Osoby z ograniczona sprawnościa na rynku pracy. Warszawa: Wydawnictwo SWPS „Academica”.

Raport AMDAI (2010) Raport access economics: the global economic cost of visual impairment, dostępny na: http://www.icoph.org/dynamic/attachments/resources/globalcostofvi_finalreport.pdf (otwarty 29.03.2016).

Rozpędek W. (2014). Polsko-amerykański wynalazek pozwoli ujrzeć świat, aktualizacja: 13.08.2014, dostępny na: http://biotechnologia.pl/biotechnologia/artykuly/ polsko-amerykanski-wynalazek-pozwoli-ujrzec-swiat,14406.html?mobile_ view=tru (otwarty 29.03.2016).

Sandberg A., Bostrom N. (2008). Whole brain emulation: a roadmap, technical report 2008-3. Oksford: Future of Humanity Institute, Oxford University.

Szkaradek M., Futyma-Ziaja M., Lewicka-Chomont A., Rejdak R. (2013). Protezy siatkówkowe: technologia umożliwiająca odzyskanie wzroku. "Okulistyka”, nr 16 (3), s. 58-6o.

Tamborska-Zedlewska M. (2004). Eugenika-zagrożenie przeszłości i teraźniejszości. „Poznańskie Zeszyty Humanistyczne”, t. 3, s. 203-210.

Tomala L. (2014). Precyzyjne sztuczne oko coraz bliżej, dostępny na: http://www. nauka.gov.pl (otwarty 12.10.2015).

Walter Ch. (2006). Thumbs, toes, and tears: and other traits that make us human. New York: Walker \& Company.

Wapiennik E., Piotrowicz R. (2002). Niepelnosprawny - petnoprawny obywatel Europy. Warszawa: Urząd Komitetu Integracji Europejskiej. 
Wiazowski J. (2001). Komputery i sieci komputerowe jako media wspomagajace nauczanie języka angielskiego uczniów niewidomych. „Języki Obce w Szkole”, nr 7, s. 87-92.

Wiazowski J. (2009). Niewidomi a rewolucja technologiczna - doświadczenia amerykańskie. „Niepełnosprawność i Rehabilitacja”, nr 3, s. 83-99.

Wojtkowski M. (2009). Obrazowanie za pomoca tomografii optycznej OCT z detekcja fourierowska. Toruń: UMK.

World health report (2002; 2011). Genewa: World Health Organisation, dostępny na: http://www.who.int/whr/2002/en/whro2_en.pdf?ua=1 (otwarty 29.03.2016); http://www.who.int/disabilities/world_report/2011/report.pdf (otwarty 29.03.2016).

Young S. (2006). Designer evolution: a transhumanist manifesto. New York: Prometheus Books.

Zaorska M. (2014). Pedagogika specjalna w XXII wieku? W: Jachimczak B., Pawelczak K., Wojciechowska A. (red.). Miejsce Innego we współczesnych naukach o wychowaniu. Inny w przestrzeni społecznej. Poznań: UAM.

Żekanowski C. (2001). Diagnostyka molekularna: zadania i pytania. „Wszechświat”, Z. 1/3, s. 17-23.

Żekanowski C. (2003). Nowa genetyka a niepetnosprawni. Osoba i osobnik, czyli meandry eugeniki. Cz. 2. „Retina”, nr 2 (11), Biuletyn Polskiego Stowarzyszenia Retinitis Pigmentosa, dostępny na: http://retina-forum.pl (otwarty 5.07.2015).

\title{
REHABILITATION AND EDUCATION OF PEOPLE WITH VISUAL IMPAIRMENTS IN TIMES OF DEVELOPMENT OF NEW TECHNOLOGIES AND SCIENCES
}

\begin{abstract}
People of present times are facing a technological revolution, resulting from the intensive development of sciences, which forces rapid changes in the surroundings. In case of people with sight dysfunctions, development of new technologies creates some independence in gathering information, which was impossible before, and makes their participation in social life even more complete. It is an opportunity to avoid a disability or to reduce its consequences in a significant way. The goal of the presentation is to show the latest scientific achievements related to education, diagnosis and rehabilitation of people with sight dysfunctions.
\end{abstract}

Key words: new technologies, education, rehabilitation, sight

Marzena Dycht - doktor habilitowana, profesor Uniwersytetu Kardynała Stefana Wyszyńskiego w Warszawie. Wybrane publikacje: Henryk Ruszczyc. Pedagogiczne inspiracje (2012), Koncepcja pedagogiki specjalnej Zofii Sękowskiej (2008), Koncepcja tyflopedagogiki w ujęciu Zofii Sękowskiej (2005). Adres do korespondencji: Wydział Nauk Pedagogicznych UKSW, ul. Wóycickiego 1/3, bud. 15, 01-938 Warszawa. Adres e-mail: m.dycht@uksw.edu.pl. 